\title{
0 direito e 0 avesso: análise semiótica do discurso político e empresarial
}

\section{Izidoro Blikstein}

- Professor titular em Linguística e Semiótica pela Universidade de São Paulo

- Livre-docente e doutor em Linguística pela mesma universidade

- Professor Adjunto na área de Comunicação e de Comunicação Empresarial na Fundação Getulio Vargas (FGV-SP)

- Especialista em Literatura Sânscrita e Mestre em Linguística Comparativa pela Université Lumière Lyon 2

- Graduado e especialista em Letras Clássicas pela Universidade de São Paulo

- Consultor da Fundação de Amparo à Pesquisa do Estado de São Paulo (Fapesp)

- Possui vasta experiência em publicação editorial e em participação em congressos nacionais e internacionais nas áreas de linguística, semiótica e comunicação empresarial

- Entre seus livros publicados, encontram-se Técnicas de Comunicação Escrita (2007), Como Falar em Público - Técnicas de Comunicação para Apresentações (2006) e Kaspar Hauser ou A Fabricação da Realidade (1983)

- izidoro@blikstein.com 
Resumo

Aborda-se a natureza dialógica do discurso e sua função para demonstrar como o discurso empresarial manipula os signos, por meio de uma narrativa marcada por estereótipos e incoerências semânticas. Desconstruindo discursos utilizados em situações reais, o autor exemplifica e esclarece como a estratégia discursiva pode contornar uma questão embaraçosa e causar um efeito positivo. Discute-se o dilema de ordem ética que as empresas vivenciam ao perseguirem um efeito de sentido favorável para seus produtos e sua imagem. $\mathrm{O}$ autor mostra que o discurso não é dito por uma única voz, mas por muitas vozes, geradoras de textos que se entrecruzam no tempo e no espaço.

PALAVRAS-CHAVE: DISCURSO • SEMIÓTICA • DISCURSO EMPRESARIAL

\section{Abstract}

The dialogical nature of the speech, as well as of its function, is analyzed with the purpose of showing how business discourse manipulates the signs, by means of narration that is marked by stereotypes and semantic incoherence. By deconstructing speeches used in real situations, the author offers examples and clarifies how discursive strategy can circumvent an embarrassing issue and cause a positive effect. The article also discusses the ethical dilemma that companies experience when pursuing an effect with a favorable meaning for their products and images. The author shows that the discourse is not enunciated by one single voice, but rather by many voices that generate texts that intercross in time and in space.

KEYWORDS: SPEECH • SEMIOTIC • BUSINESS DISCOURSE

Resumen

Se abordan la naturaleza dialógica del discurso y su función, con el objetivo de demostrar cómo el discurso empresarial manipula los signos, por medio de una narrativa marcada por estereotipos e incoherencias semánticas. Al deconstruir discursos utilizados en situaciones reales, el autor ejemplifica y aclara cómo la estrategia discursiva puede evitar una cuestión embarazosa y causar un efecto positivo. El artículo debate también el dilema de orden ético que las empresas viven al perseguir un efecto de sentido favorable a sus productos y su imagen. Se muestra que el discurso no es enunciado por una única voz, sino por muchas voces, generadoras de textos que se entrecruzan en el tiempo y en el espacio.

PALABRAS CLAVE: DISCURSO • SEMIÓTICA • DISCURSO EMPRESARIAL 
D iante da insatisfação e dos protestos da população, por causa das graves falhas do controle do tráfego aéreo que têm ocasionado permanentes atrasos, cancelamento de vôos e filas intermináveis nos aeroportos do Brasil inteiro, Mr. Nelson Jobim, ministro da Defesa do atual governo brasileiro, procurou tranquilizar a opinião pública e a imprensa, ao afirmar que a situação estava sob controle, argumentando categórico: "A fiscalização existe. A eficácia dessa fiscalização é que é o problema.” (TOLEDO, 2007, p. 190).

How come? Como é possível que, sem eficácia, a fiscalização exista? Não precisamos de uma análise mais profunda para considerar a frase do ministro talvez uma brincadeira, uma ironia ou, melhor ainda, um nonsense, e mesmo um bullshit. Mas o ministro falava seriamente, assegurando que, apesar do caos aéreo, a situação estava controlada... embora sem a fiscalização eficaz.

De fato, o ministro não estava brincando: o que ele fez foi usar uma estratégia discursiva para contornar uma questão embaraçosa e causar um efeito positivo nos ouvintes. É preciso dizer algo. É uma falha não dizer nada. É preciso preencher o vazio. É bom lembrar que tal estratégia não é nova e nem específica de uma cultura ou um país. Flaubert, em suas críticas mordazes ao discurso estereotipado e vazio da sociedade burguesa, já apresentara, no Dictionnaire des idées recues (2002) um enorme dossiê das bullshits humanas que, segundo ele, deveriam ser ditas na sociedade sempre que desejássemos produzir a imagem positiva de alguém conveniente e amável. Eis alguns exemplos:

- Aquiles - sempre acrescentar "de pés ligeiros", o que leva a crer que lemos Homero;

- Adolescente - começar um discurso de distribuição de prêmios sempre por "jovens adolescentes";

- Alemanha - Que organização militar!;

- Ambição - sempre precedida de "louca" quando ela não é nobre;

- Ingleses - todos ricos;

- Bandidos - todos ferozes;

- Banqueiros - Todos ricos. Árabes etc.;

- Negras - mais quentes do que as brancas;

- Vinhos - o melhor é o Bordeaux, pois os médicos o aconselham;

- Rosto - espelho da alma;

- Pudor - o mais belo ornamento da mulher.

Para Flaubert, poderiam figurar no Dictionnaire ilustres personalidades, como Fénelon, para quem "a água é feita para sustentar estes prodigiosos edifícios flutuantes que denominamos navios" e Louis-Napoléon, para quem "a riqueza de um país depende da prosperidade geral” (FLAUBERT, 1966, p. 19-21).

É relevante lembrar que o autor explica o funcionamento desse discurso do nonsense a partir do pressuposto de que: "A besteira humana consiste em querer sempre concluir.” (FLAUBERT, 1966, p. 25). Assim, graças a Flaubert, podemos 
também explicar o mecanismo das estratégias discursivas, produzidas para enfrentar questões dificeis e comprometedoras: trata-se de construir uma narrativa que contenha uma conclusão. Em outras palavras, é preciso concluir para dar sentido à narrativa (sensemaking), como tão bem demonstrou Weick (1990).

Pelo exposto, a função do discurso não é propriamente informar: do ponto de vista semiótico, o discurso tem, basicamente, a função de criar um efeito no receptor da mensagem. No caso do discurso empresarial, o discurso deve criar uma imagem positiva, mostrando a empresa como uma organização competente, ética e transparente. $\mathrm{Na}$ prática, entretanto, o discurso empresarial funciona de modo a "esconder" mais do que "mostrar". Com efeito, a análise semiótica e linguística revela como o discurso empresarial é articulado, na estrutura de superfície, para transmitir uma imagem de perfeição e de heroísmo (como uma manifestação da síndrome de John Wayne, o invencível "cowboy”), embora, na estrutura profunda, tal discurso contenha os pressupostos típicos de uma intertextualidade autoritária, conservadora e discriminatória.

No presente artigo, nosso objetivo é demonstrar como, frequentemente, o discurso empresarial manipula os signos, por meio de uma narrativa marcada por estereótipos e incoerências semânticas. Tal manipulação é articulada pela "técnica" do silêncio a respeito de aspectos essenciais do conteúdo da mensagem. O discurso procura, então, encobrir o essencial, dando ênfase a detalhes. Mas sabemos que Deus se esconde nos detalhes...

Para a semiótica, a verdadeira significação do discurso pode ser extraída do "pequeno": o "pequeno" conduz ao "grande", segundo a brilhante expressão de Ginzburg (1984) ao apontar as semelhanças entre os métodos de descoberta praticados por Freud, Sherlock Holmes e o crítico de pintura Morelli.

\section{A natureza dialógica do discurso}

Em entrevista realizada no final de seu mandato, o então presidente Fernando Henrique Cardoso, quando indagado sobre como se sentia "... nas vésperas de passar a faixa presidencial para um líder operário...”, declarou:

"Eu acho que é isso o que me deixa mais contente. Quer dizer, naturalmente, qualquer outro que fosse eleito eu teria uma satisfação imensa ${ }_{2}[\ldots]$ mas é claro que há um significado especial em passar para um líder operário, para um homem que vem de lutas sindicais, um homem que eu conheci nos anos 70, quando havia ainda uma ditadura e nós estivemos juntos em muitas campanhas, de modo que isto a mim me dá, eu diria, uma emoção. Eu espero com ansiedade o momento em que o mundo todo vai ver, mesmo que seja inabitual que uma pessoa com formação acadêmica, como a que eu tive, chegasse à Presidência, mais inabitual ainda que a faixa seja transmitida a um líder operário, e verão que mais inabitual ainda que será feito com esse espírito brasileiro que é de cordialidade" (FOLHA DE SÃO PAULO, 2002, p. 3, grifo nosso). 
Aparentemente, o sentido do texto é bem claro e não deixa margem a dúvidas: o presidente se diz contente, e até emocionado, por passar a faixa presidencial não a um mero candidato eleito, mas, em especial, a um líder operário, sindicalista e ativista político que lutou contra a ditadura. No entanto, uma releitura atenta poderá conduzir-nos a detectar, nas dobras desse mesmo discurso, significados implícitos que podem conferir-lhe um sentido bem diferente.

Com efeito, basta observar a abundante recorrência a adjetivos, advérbios e expressões "superlativas", com que o sujeito do discurso valoriza o gesto de "passar a faixa":

- é isso que me deixa mais contente

- eu teria uma satisfação imensa

- isto a mim me dá, eu diria, uma emoção

- espero com ansiedade

Esse investimento superlativo parece reiterar o pressuposto básico de que "passar a faixa” é habitualmente, uma atitude eufórica do presidente, pois teria, naturalmente, uma satisfação imensa com qualquer candidato. Esse gesto, todavia, agora se torna magnânimo, na medida em que o eleito é especial, ou, mais ainda, inabitual: além de líder operário e sindicalista, o candidato é:

- um homem que eu conheci nos anos 70

- quando havia ainda uma ditadura

- e nós estivemos juntos em muitas campanhas

O sujeito do discurso coloca-se, assim, como tão especial quanto o líder operário. E não só especial, mas, sobretudo, inabitual, pois não é usual que:

- uma pessoa de formação acadêmica, como a que eu tive, chegasse à Presidência

Mas há algo mais inabitual ainda que o mundo todo vai ver, a saber, a transmissão da faixa será feita:

- com esse espírito brasileiro que é de cordialidade

Eis, talvez, o pressuposto-chave desse enunciado: o mundo inteiro é testemunha de que, ao transmitir a faixa, o presidente, tão excepcional quanto o sucessor, é, sobretudo, democrata, magnânimo e cordial. Cabe uma pergunta: por que reiterar de forma tão superlativa a excepcionalidade e, principalmente, a cordialidade do gesto? Talvez porque a transmissão do cargo a um inabitual adversário político não seja naturalmente cordial. Esse poderá ser, então, o outro sentido do texto: o presidente é sempre cordial e sua cordialidade é exaltada pela ausência da não cordialidade. 
Fica bem ilustrado o princípio fundamental da análise linguístico-semiótica do discurso: todo enunciado poderá ser lido em seu "direito" ou em seu "avesso". A transmissão da faixa ao eleito não é o tema central: o eixo do discurso é, em última análise, a oposição cordial vs não cordial. Estamos, portanto, diante de um diálogo entre dois textos e duas vozes: cordialidade vs não cordialidade.

Dialogismo, intertextualidade e polifonia estão na própria essência do conceito de discurso, tal como foi proposto por Bakhtin (1992) para constituir seu discurso, o enunciador tem de, inevitavelmente, levar em conta outros discursos que estarão em oposição dialógica com o seu próprio.

Pelo exposto, nenhum discurso é, em princípio, totalmente autônomo, monológico e monofônico. Suportado por toda uma intertextualidade, o discurso não é dito por uma única voz, mas por muitas vozes, geradoras de textos que se entrecruzam no tempo e no espaço, a tal ponto que, muitas vezes, faz-se necessária uma escavação linguístico-semiótica para recuperar a significação profunda dessa polifonia. A tarefa linguístico-semiótica será, então, detectar a rede de isotopias ou eixos semânticos, como é o caso de cordialidade vs não cordialidade que governam as vozes, os textos e, finalmente, o discurso.

Tal escavação nos revelará como o sentido primeiro de um enunciado nem sempre corresponde necessariamente (e, em certos campos, como o político, quase nunca) à significação profunda do intertexto em que se teceu o discurso. Em outros termos, o discurso parece tratar do referente $X$, quando, na verdade, o tema é o referente Y, oculto nas malhas da intertextualidade. É a ilusão referencial. O enunciador leva o destinatário a dois níveis de descodificação: um, no plano da superfície, em que se capta o referente X (ilusório); outro, na estrutura profunda do intertexto, em que se absorve, "inconscientemente", o referente $Y$, correspondente às verdadeiras intenções do enunciador. A natureza do discurso tende a ser, destarte, intertextual, dialógica e polifônica.

\section{Função do discurso}

Poderia caber uma objeção: na medida em que pode abrigar níveis de sentido diversos, suscitando, então, diferentes leituras de uma mesma mensagem, será que essa natureza dialógica e polifônica não desfiguraria o modelo clássico da comunicação (emissor, código, mensagem, receptor, entendimento e retroalimentação)?

Ocorre que tal modelo é um truísmo insuficiente para explicar o funcionamento do discurso na comunicação, pois este vai além de transmissão de informações de um emissor para um receptor. É oportuno lembrar agora Émile Benveniste, cujas observações sobre a função do discurso permitem compreender o alcance da natureza dialógica proposta por Bakhtin. Segundo Benveniste (1974), o discurso se caracteriza: 
- por uma enunciação, a qual supõe um enunciador e um destinatário (ou enunciatário, e não apenas um mero receptor);

- pela intenção do enunciador em gerar um efeito no destinatário, a fim de obter-lhe a colaboração ou resposta desejada.

É evidente que o efeito deve ser positivo ou favorável, para que o destinatário produza a resposta desejada pelo enunciador. O dialogismo e a polifonia permitem ao enunciador conduzir (ou não) o destinatário, de forma velada, sutil, implícita, para o efeito e a resposta desejada. Os ingredientes geradores do efeito positivo (ou negativo) residem justamente no avesso, no nãa dito, no intertexto.

Cruzamo-nos aqui com a função conativa da linguagem, tal como foi proposta por Roman Jakobson (2000), no conhecido modelo das seis funções da linguagem: referencial, emotiva, conativa, metalinguística, fática e poética.

A natureza dialógica (Bakhtin) e a função geradora de efeitos (Benveniste) parecem estar contempladas pela função conativa, cujo objetivo básico é obter a resposta do destinatário. Tal resposta pode ser obtida por estratégias coercitivas e autoritárias (ordens, uso do imperativo: "faça!"). O dialogismo e a polifonia permitem, contudo, que a adesão do destinatário se realize de modo mais implícito, sutil, "inconsciente".

É por esse itinerário teórico que desembocamos no conceito de persuasão. É oportuno lembrar que, etimologicamente, persuadir - da mesma origem da palavra suave - significa "convencer de modo doce, suave". Pelo exposto, a função do discurso é, então, persuadir o destinatário, isto é, convencê-lo de forma suave, sutil, o que pode tornar a persuasão uma forma velada de manipulação. Em última análise, o discurso tem a função de fazer crer e, consequentemente, fazer fazer.

É o caso do discurso nazista. Com a frase Arbeit macht frei, "o trabalho faz (ou traz) a liberdade", os administradores dos campos de concentração tinham a intenção de persuadir os prisioneiros a crerem na nobreza do trabalho; tal aviso, no entanto, estava enredado nas malhas da intertextualidade da doutrina do arianismo, baseada na oposição ariano (aquele que trabalha) vs não ariano (aquele que não trabalha). Dentre os vários exemplos de discursos nazistas de cunho moralista e educativo, vale citar um texto cujo objetivo é "persuadir" os prisioneiros a alcançarem o caminho da liberdade, cultivando as seguintes qualidades: obediência, zelo, honestidade, ordem, propriedade, temperança, verdade, espirito de sacrificio e amor pela Pátria (BERBEN, 1976).

Parece claro que tais qualidades "arianas" se encontram no "direito" do enunciado, enquanto no "avesso" está dito que os prisioneiros (os não arianos ou as anti-raças) não têm nenhuma dessas mesmas qualidades; considerando que seria impossível cultivá-las no cenário perverso dos campos de extermínio, fica 
também implícito que a liberdade nunca será alcançada. Vale observar que pode haver duas percepções para esse mesmo discurso:

1. Para a análise linguístico-semiótica, que permite a detecção dos níveis de sentido (direito e avesso), trata-se de um discurso manipulatório;

2. Para os enunciadores e destinatários, o discurso não tem dois lados: ele é explícito, monológico e monofônico. O destinatário deve crer que o caminho da liberdade passa, obrigatoriamente, pela prática das qualidades "decretadas" pelos administradores dos campos.

E o discurso empresarial? Não deve ser ele monofônico, a fim de comunicar de modo explícito a missão, as metas, a filosofia de gestão, os produtos e as mudanças da organização? É o que veremos a seguir.

\section{0 discurso empresarial}

Já é lugar-comum falar da importância da comunicação para as empresas e o ensino da ciência da administração proclama que a comunicação é a ferramenta básica para propiciar visibilidade interna e externa da empresa, na medida em que possibilita não só a produção e distribuição, mas também a recepção de informações que circulam para dentro e para fora da organização.

Ao zelar pela qualidade dos diversos fluxos de informação que circulam interna e externamente na organização, a comunicação empresarial deve, portanto, produzir um discurso estratégico, qual seja o de gerar um efeito positivo nos acionistas, nos stakeholders, nos clientes, no mercado e na sociedade, de modo a preservar a identidade e a imagem da instituição.

Numa primeira instância, tal discurso deve ser, em princípio, transparente, explícito e monofônico. Mas, na prática, ocorre que, para gerar efeitos positivos e obter a adesão do destinatário, o enunciador acaba por construir um discurso dialógico, em que se desenvolve uma relação polêmica entre o texto e o intertexto, o dito e o não dito, a voz explícita e a voz implícita. Essa obsessão pelo efeito positivo e, consequentemente, pela imagem sempre favorável da organização, é o que se pode denominar a sindrome John Wayne (o herói imaculado e imbatível). Qualquer que seja a dimensão de uma crise, a empresa teria de, permanentemente, ostentar uma imagem favorável. Mas ocorre que o discurso dialógico e polifônico nem sempre gera efeitos positivos. Vejamos alguns casos.

0 caso da empresa ALFA: A ALFA, empresa responsável pela administração do turismo, recebeu a seguinte carta de uma cliente insatisfeita com o atendimento:

“...liguei para a ALFA e pedi o telefone de uma empresa de turismo de Campinas. Fui atendida por um senhor de nome Manuel, que não está classificado 
nem para atender porta, quanto mais telefone. Pois bem, pedi-lhe o nome da empresa e, antes de verificar na listagem ou computador... ele já disse que o nome não estava certo. Retruquei que era impossivvel ele saber, pois não havia consultado nenhuma lista. Dai ele disse para ligar mais tarde, pois a pessoa que poderia me atender estava ocupada e não iria parar de fazer o que estava fazendo. A ALFA não é um órgão que tenta passar imagem de perfeição e ajuda ao turismo?..."

Eis a resposta da ALFA:

"Esclarecemos que o funcionário citado não exerce a função de prestar informações ao público. Trata-se, na verdade, de um servente de idade avançada, tido, mesmo entre os seus colegas, como uma pessoa rústica. Assim, ao mesmo tempo em que lamentamos o ocorrido, informamos à leitora que todas as providências já foram tomadas no sentido de evitar a repetição desse condenável incidente. Lembramos, ainda, que todos os funcionários do Centro de Atividades Descentralizadas (Cade) fazem questão de primar pela cortesia e pelo bom atendimento." (O ESTADO DE SÃO PAULO, 1994, p. 2, grifo nosso).

Numa primeira leitura, percebe-se o empenho do enunciador em desfazer a má impressão e gerar um efeito positivo, por meio da menção explícita aos funcionários do Cade (nome longo e sofisticado), que primam pela cortesia. Se os funcionários da ALFA atendem bem, quem será o culpado pelo "condenável” incidente? O servente Manuel, é claro. E o enunciador constrói um diálogo polêmico: cortesia da ALFA vs rusticidade de Manuel. Essa rusticidade é explicada por tratar-se de um servente de idade avançada. No avesso do discurso, o sentido mais profundo é instaurado pela oposição discriminatória e preconceituosa entre juventude/cortesia/competência vs velhice/grosseria/incompetência. Nesse caso, a almejada imagem de perfeição é "arranhada" pelo pressuposto de que a causa da incompetência é a velhice rabugenta. O discurso poderia ser monofônico e transparente: "Erramos".

$\mathbf{O}$ caso da empresa BETA: Em razão de reportagem em que se questionava a pureza da água distribuída pela empresa BETA, essa organização, para defender seu produto e sua própria imagem, publicou a seguinte Nota Oficial na imprensa: "A BETA... vem mais uma vez a público, para garantir a qualidade da água que distribui a mais de 24 milhões de pessoas e afirmar que estão equivocadas as informações contidas em reportagem sobre a presença de germes na água distribuida para a população... Essas afirmações poderão induzir, inadvertidamente, ao consumo de água em fontes alternativas e não controladas, nem pela BETA nem pela vigilância sanitária, o que representa riscos concretos à saúde pública. A BETA é uma empresa que prima pela qualidade da água que distribui e, por isso, teve todos os seus laboratórios certificados pela ISO 9002. A presença do protozoário 'criptosporidium' é um fato comum em águas de abastecimento, em todo o mundo. Em vários países, os cientistas estão fazendo pesquisas sobre as melhores técnicas para detectar e eliminar esse germe das águas para distribuição. Essas pesquisas ainda não estão concluidas, nem mesmo nos Es- 
tados Unidos, onde a rigorosa EPA - Agência América Ambiental - ainda não definiu os padrões mínimos aceitáveis da presença do 'criptosporidium'. São Paulo coloca-se ao lado das grandes nações ao apoiar pesquisa realizada pela Universidade... As amostras que serviram como base para a pesquisa... indicam valores totalmente idênticos àqueles encontrados nas águas distribuidas nas cidades dos Estados Unidos, Canadá e outros países." (O ESTADO DE SÃO PAULO, 2000, p. 1).

Parece que, se a BETA pretendia gerar um efeito positivo, o resultado foi exatamente contrário a essa intenção, por várias razões:

1. Há uma flagrante contradição entre negar a presença de germes e, depois, afirmar que estão sendo feitas pesquisas "para eliminar esse germe";

2. A verdadeira qualificação da empresa não é a outorgada pela ISO 9002, mas está baseada no pressuposto de que, ao conter os mesmo germes que se encontram nas águas americanas e canadenses, a BETA está no mesmo nível das empresas de Primeiro Mundo.

3. Outro pressuposto é o de que a BETA não é rigorosa, uma vez que o avesso do discurso qualifica como rigorosos os Estados Unidos e a Agência América Ambiental. Essa qualificação se produz por meio de duas expressões não muito perceptíveis numa primeira leitura, quase não ditas (embora tenham sido ditas):

- "nem mesmo os Estados Unidos"

- "onde a rigorosa EPA"

Essas duas "pequenas" e "rápidas" expressões instauram, na verdade, a oposição fundamental do texto, escondida no intertexto: Primeiro Mundo competente vs Terceiro (?) Mundo incompetente. Ao partir dessas "fugazes" expressões para chegar aos grandes pressupostos do discurso, parece-nos possível demonstrar o alcance do método da semiótica, o qual consiste em decifrar o "grande" através do "pequeno", pois o que realmente interessa à semiótica não é o visível, mas o inteligível.

A ideia de que o "pequeno" conduz ao "grande" está impecavelmente sintetizada na frase Deus se esconde nos detalhes, de Flaubert e Warburg, citada em epígrafe no artigo "Chaves do Mistério: Morelli, Freud e Sherlock Holmes", quarto e brilhante ensaio de Carlo Ginzburg, publicado em O Signo de Três, de Umberto Eco e Thomas Sebeok (1991). No artigo, Ginzburg aponta o paralelismo entre Sherlock Holmes, Freud e o crítico de pintura Giovanni Morelli, ressaltando o fato de que Freud ficara impressionado com o método interpretativo de Morelli, baseado na apreensão de detalhes marginais e irrelevantes enquanto chaves reveladoras.

Para Morelli, o pormenor insignificante é revelador na medida em que, como dificilmente pode ser falsificado ou camuflado (já que não é premeditado), 
pode conduzir à revelação do conjunto a que pertence. Outro não é o procedimento de Freud, ao deter-se nos pequenos lapsos de memória ou de linguagem para explicar, por exemplo, o esquecimento dos nomes próprios.

O caso da empresa DELTA (SEGNINI, 1988): Os candidatos a um emprego na empresa DELTA devem preencher uma condição básica para sua admissão, a saber, ler atentamente e praticar fielmente as regras de dois documentos: 1. A Declaração de Princípios e 2. O Regulamento Disciplinar Interno.

A análise linguístico-semiótica desses textos demonstra como o efeito de sentido desejado pela organização é arquitetado por um diálogo entre o discurso da normalidade comportamental vs a anormalidade comportamental. O efeito de sentido desejado é que os funcionários da instituição tenham um comportamento normal. Esses documentos devem ser lidos, assinados e praticados pelos funcionários. Não será difícil detectar nesses textos o direito e o avesso: a afirmação de uma qualidade já implica a negação de um defeito, o qual se encontra num discurso implícito, em permanente polêmica com o explícito.

A Declaração de Princípios reflete o ethos da empresa. Eis alguns dos princípios: "Eu, fulano de tal, prometo, solene e fielmente, com otimismo e entusiasmo, que seguirei os princípios que a seguir declaro:

- Amar o Brasil, dedicando-me integralmente a ele e trabalhando sempre mais e melhor, até onde minhas forças permitirem.

- Colocar os interesses públicos, os da instituição e demais organizações acima dos meus próprios interesses.

- Dentro da convicção de que "só o trabalho pode produzir riquezas", agir com plena dedicação, com todo o meu amor, minha disciplina e justa humildade.

- Respeitar e manter o princípio da hierarquia, condição essencial, quer no Estado, na Família e na Sociedade, para o aprimoramento do homem" (Grifo nosso).

No Regulamento Disciplinar Interno, vale destacar as seguintes regras:

- "trajar-se de modo conveniente e asseado, mantendo sua aparência fisica sem exageros e extravagâncias;

- zelar pela limpeza e boa ordem do local de trabalho..."

Percebe-se, nesses princípios e regras, a exaltação do amor à pátria, da coletividade, do trabalho e da limpeza. Não deve ser exagero encontrar exaltação semelhante na intertextualidade da doutrina nazista em que se contemplam, como nos já citados aforismos nos campos de concentração, os pressupostos da obediência, da ordem, da limpeza e do amor à pátria, acima de tudo. A entronização do trabalho, como caminho para a liberdade e para a riqueza fica patente no paralelismo das duas fórmulas:

- "Arbeit macht frei"

- "Só o trabalho pode produzir riquezas" 
Mas a primazia do coletivo sobre o individual já fora proclamada, em 1924, pelo discurso de... Adolfo Hitler (1983, p. 194):

"A coroação de todo espirito de abnegação reside no sacrificio da própria vida individual em prol da existência coletiva [...]

[...] o idealismo genuíno não é mais nem menos do que a subordinação dos interesses e da vida do individuo à coletividade... Só ele é que conduz os homens a reconhecerem espontaneamente o privilégio da força e do vigor, fazendo deles uma poeirazinha insignificante..."

\section{Observações finais}

Pelo exposto, as organizações podem estar diante de um dilema de ordem ética: na obsessão de perseguir um efeito de sentido favorável para seus produtos e sua imagem, o discurso empresarial pode comprometer-se com uma intertextualidade cujas vozes nem sempre são portadoras de conteúdos propriamente éticos. Tal envolvimento poderá levar a formulações contraditórias e incoerentes que beiram, muitas vezes, o absurdo semântico.

Esse absurdo semântico encontra um de seus exemplos mais perversos na normalidade, e até na naturalidade, de que se investiu o discurso dos técnicos que se empenharam na construção de incineradores cada vez mais eficazes e econômicos em Auschwitz, Dachau, Buchenwald etc. Tal naturalidade fica evidente nos comentários de Jean Claude Pressac (1993), em sua pesquisa sobre o funcionamento dos fornos crematórios de Auschwitz:

"O construtor indicava, sugerindo assim a possibilidade de incinerar em série, que a segunda e a terceira incineração não exigiam nenhum combustivel suplementar e que as seguintes poderiam ser praticadas quase sem acréscimo de combustivel, apenas com insuflação de ar no crisol. Ele estimava em uma hora e meia a duração de incineração de um corpo de $70 \mathrm{~kg}$ num caixão de madeira de $35 \mathrm{~kg}$. A partir desses dados, os SS deduziram que incinerar um corpo sem caixão permitiria ganhar uma meia hora e que, de manhã, $100 \mathrm{~kg}$ de coque lhes seriam suficientes para reduzir a cinzas uma vintena de corpos durante o dia..."

Tal discurso - que poderia ter sido extraído de uma peça de Ionesco, Beckett ou Jarry - não seria tão absurdo assim: mudando os nomes, o espaço e o tempo, os argumentos utilizados, em 1939, pelo "competente" construtor de fornos industriais, o engenheiro Kurt Prüfer - da Topf und Söhne, firma vencedora da concorrência para a construção dos incineradores nos campos nazistas - poderiam perfeitamente caber agora numa proposta em que uma empresa procurasse persuadir o cliente das vantagens de seus produtos.

Ao nos conscientizarem dos pressupostos alojados na intertextualidade dos discursos, a linguística e a semiótica podem contribuir significativamente para garantir nossa liberdade de pensamento... pelo menos. 


\section{Referências}

BAKHTIN, M. Marxismo e filosofia da linguagem. Trad. Michel Lahud e Yara Frateschi Vieira. São Paulo: Hucitec, 1992. BENVENISTE, E. Problèmes de linguistique générale. Paris: Gallimard, 1974.

BERBEN, P. Histoire du camp de concentration de Dachau. Bruxelles: Comité International de Dachau, 1976.

ECO, U.; SEBEOK, T. 0 signo de três. Trad. Silvana Garcia. São Paulo: Perspectiva, 1991.

FLAUBERT, Gustave. Préface. In: . Bouvard et Pécuchet. Paris: Garnier-Flammarion, 1966. p. 19-21,

Dictionnaire des idées reçues. Paris: Éditions du Boucher, 2002.

Folha de São Paulo, Caderno Especial, 29/10/2002, p. 3.

GINZBURG, Carlo. Chaves do Mistério: Morelli, Freud e Sherlock Holmes. In: ECO, U.; SEBEOK, T. 0 signo de três. Trad. Silvana Garcia. São Paulo: Perspectiva, 1991.

HITLER, A. Minha Luta. São Paulo: Moraes, 1983.

JAKOBSON, R. Linguística e comunicação. Trad. de Isidoro Blikstein e José Paulo Paes. 17ª ed. São Paulo: Cultrix, 2000.

0 Estado de São Paulo, Nota Oficial, 18/03/2000, p. 1.

. Caderno Cidades, São Paulo Reclama, 26/03/1994, p.2

PRESSAC, J. Cl. Les crématoires d'Auschwitz. Paris: CNRS Éditions, 1993.

SEGNINI, L. A liturgia do poder. São Paulo: Educ, 1988.

TOLEDO, Roberto Pompeu. Autoridade é uma coisa, eficácia é outra. Veja, São Paulo, ano 40, n. 35, p. 190, 14 nov. 2007.

WEICK, K. The Vulnerable System: An Analysis of the Tenerife Air Disaster. Journal of Management, v. 3, n. 16, p. 571-596, 1990. 